\title{
Utilization of Library and Information Resources By Visually Impaired Primary School Pupils In Special Education Centres In South-East Nigeria
}

\author{
Esther Ekene AGHAUCHE (Ph. D) ${ }^{1}$ \& Obiora Kingsley Udem ${ }^{2}$ \\ Department of Library and Information Science ${ }^{1}$ \\ Nnamdi Azikiwe University, Awka ${ }^{2}$ \\ E-mail: ee.aghauche@unizik.edu.ng, ok.udem@unizik.edu.ng
}

Abstract

Purpose: The study investigated the utilization of library and information resources by visually impaired primary school pupils in special education centres in South-East Nigeria.

Methodology: The study adopted descriptive survey research design. The population comprised 129 respondents, consisting of 125 visually impaired pupils and 4 librarians. The entire populations were studied. Two instruments used for data collection were focus group discussion and interview. Focus group discussion was used for the students while interview was used for the librarians. Data collected were analyzed qualitatively.

Findings: The result of the study showed that visually impaired primary school pupils were not making use of available resources to a high extent, due to non-availability of resources in alternative formats.

Implications: Not making use of available resources to a high extent, due to nonavailability of resources in alternative formats shows that there is need to provide alternative format of information resources for the visually impaired pupils.

Value/Originality: The study's educational value rest on the recommendations that information resources should be provided in alternative formats of Braille, audio and digital in all the subjects taught in the special education centres and that the government should employ Braille typists since the older ones were retired.

Keywords: Utilization, Library and Information Resources, Visually Impaired, Primary School Pupils, South-East, Nigeria

\section{Introduction}

Education and access to information are fundamental human rights of all children, but primary school pupils who are visually impaired

Visually impaired primary school pupils are pupils in primary schools with sight loss that cannot be improved by corrective lenses to enable them read as others. Visual impairment is a disability that is associated with loss of vision. It refers to people with irretrievable sight loss and it covers a range of impairments. Vision is one of the five senses of human beings and is associated with sight. The eye has different parts that work together to create ability to see. When a part of the eye does not work right or communicate well with the brain, vision is impaired (NICHCY, 2012). Visual encounter obstacles realizing these rights, thereby not meeting their full potentials. This is because the nature of their disability presents grievous obstacles to their acquiring information that enhances teaching and learning.

impairment refers to people with a wide spectrum of impairments. Ugwu (2008) asserted that it is an umbrella term referring to various degrees of defects in eye function or structure, ranging from the slightly impaired to the completely blind. Rayini (2017) also opined that 'visually impaired' is a general term used to describe people who are partially sighted or completely blind. However, the Copyright (Visually Impaired Persons) Act 2002, broadly defined a visually impaired person (VIP) as someone who is blind, partially sighted and whose eyesight cannot be improved by corrective 
lenses to allow them to read without a special level or kind of light, who is unable to either hold or manipulate a book or move the eyes to be able to read easily. In other words, any person who is not able to read in a conventional way is visually impaired.

Visual impairment affects how a child understands and functions in the world. It can affect a child's cognitive, emotional, neurological and physical development by limiting the range of experiences and kinds of information a child is exposed to. This is why Eguavoen and Eniola (2007) noted that a young child with visual impairment has little reason to explore interesting objects in the environment and thus may miss opportunities to have experiences and learn, and that this lack of exploration may continue until intervention.

Education is the key to overcoming the challenges of visual impairment and achieving success. Moreover, it is a human right that should be accorded to all human beings. The UN Convention on the Right of the Child (1990) in article 23(3) states that efforts should be made to ensure that the disabled child has effective access to and receives education, training, health care services, preparation for employment opportunities in a manner conducive to the child's achieving the fullest possible social integration and individual development.

From the foregoing, it is obvious that education is the way forward for producing successful contributing members of the society. With the provision of better education opportunities, proper and suitable resources and adequate support, the visually impaired will fulfill their potential and achieve greatness.

In pursuance of the goals of primary education, the National Policy on Education specifies school libraries as one of the educational services. School libraries play a very important role in the educational development of children by providing library and information resources for teaching and learning. Generally, libraries house information resources. A library is a collection of resources in a variety of formats that is organized by information professionals or other experts, who provide convenient physical, digital, bibliographic or intellectual access, and offer targeted services and programmes, with the mission of education, informing or entertaining a variety of audiences, and the goal of stimulating individual learning and advancing society as a whole. Obviously, libraries, including libraries for the visually impaired, are expected to contain a variety of resources in different formats in order to meet the varying needs of users. Provision of information resources in the libraries plays a significant role in their utilization.

Given the importance of library resources in the educational development of an individual, what is the availability of these resources in libraries, especially in developing countries like Nigeria? Library resources constitute the totality of the library holdings, which include print and non-print materials in various formats and ICT resources, with which the library meets the information needs of users. Majority of library resources are in print. Since the visually impaired cannot access information in print, there is need to repackage information in a format suitable to them, that is, alternative formats. Alternative formats include Braille, audio/talking materials, large prints and ICT resources. Ajobiewe (1999) was of the opinion that the provision and use of alternative formats such as Braille, large prints, talking books and the availability of reading aids, volunteers and transcription services in libraries servicing persons with visual impairment in Nigeria would go a long way in making information accessible to the blind and partially sighted users.

Braille, which is the oldest format, involves the use of the sense of touch. Braille is a system of reading and writing whereby organized raised dots are used to represent letters and numerals that are read by touching. Audio/talking resources are another means by which the visually impaired access information. Audio resources involve the use of sense of hearing. They are audio recordings on tapes, cassettes and compact disks from books and other materials which the visually impaired can listen to, thereby providing them the opportunity of reading through listening. In recent times, Information and Communication Technology (ICT) has provided new possibilities and great potential in terms of information resources and facilities for the visually impaired. A wide range of ICT facilities, also called assistive or adaptive technologies, now exist to provide access to information, giving visually impaired users equal opportunity as the sighted. ICT is a faster means of accessing information but expensive. Software packagesare available to 
enable visually impaired learners access information. Some of these software packagesare: screen reading software e.g. JAWS, screen magnification software e.g. Zoom text and web access software e.g. Connect Out loud.

Use of information resources is very important for the educational development of visually impaired pupils. It is through the use of these resources that visually impaired pupils acquire literacy skill and access information that enhance learning. These resources could also be used for recreational reading, that is, reading for pleasure and personal development. Visually impaired pupils can also read the resources for spiritual inspiration and as hobbies. As visually impaired pupils use information resources variously, they are helped to overcome their disability.

To achieve the goals of primary education with regards to visually impaired children, government has established special education centres in different parts of the country. Four special education centres have been established in the zone. These are: Special Education Centre for the Blind, Afara-Ukwu, Umuahia, Abia State; Basden Memorial Special Education Centre, Isulo, Anambra State; Special Education Centre, Opefia, Izzi L.G.A Ebonyi State; and Special Education Centre, Oji River, Enugu State. Ideally, it is expected that these centres would provide a variety of information resources in various formats. However, the extent of use of these resources in these centres is yet to be determined. Hence, the major task of this study is to determine use of library and information resources by visually impaired primary school pupils in South East Nigeria.

\section{Statement of the Problem}

The importance of library and information resources to visually impaired pupils especially in the alternative formats cannot be over emphasized. These resources enable visually impaired pupils acquire literacy skills and access information for learning. However, the extent of use of these resources in Nigeria, particularly in the South-East is in doubt. Available literature suggests that there may be scarcity of alternative formats of information resources in libraries for the visually impaired in Nigeria. In the past, efforts have been made to provide information resources generally for primary school pupils, but this unique group has special needs that may not have been given proper attention. If this is the case, dearth of alternative formats of information resources would be consequential to low utilization. Except information resources are repackaged in alternative formats that visually impaired pupils can access, they will remain cut off from the world of information and hence deprived of education. The extent to which information resources are accessed and utilized is of paramount importance in librarianship. This is why this study is set to determine the use of information resources by visually impaired primary school pupils in South East Nigeria.

\section{Purpose of the Study}

The purpose of the study is to determine the use of library and information resources by visually impaired primary school pupils in South East Nigeria

One research question that guided the study is:

What use do visually impaired primary school pupils make of library and information resources in South East Nigeria?

\section{Review of Related Literature}

Use of information resources by visually impaired pupils has to do with visually impaired pupils consulting information resources for the purpose of satisfying their information needs. The real challenge in this information age is not producing information or storing information, but getting people to use information appropriately. Meanwhile, Onifade and Sowole (2009) rightly noted that, for libraries to add to the advancement of knowledge, they must not only provide resources but also ensure that the resources are effectively used. Effective and efficient utilization of information has contributed immensely towards the sustainable development of the society. Being able to use, read and understand communication is not only a precondition to participate in social life; it is also a key to quality of the individual. This is why Singh and Moirangthem (2010) pointed out that the modern society is characterized by the ability to identify, interpret, produce, process, transform, disseminate, use and reuse information; to make informed choices; and to share information and knowledge through effective networking mechanism.

The importance of making information accessible to the visually impaired is now realized by different countries. Information resources for the 
visually impaired must be transcribed into alternate formats before they are made available for use. However, the use of alternative formats by visually impaired is limited by availability (Adetoro, 2011). The extent to which information resources are accessed and utilized is of paramount importance in librarianship. Visually impaired pupils are encouraged to make use of information resources that the library acquires. Ajobiewe (1999) opined that the provision and use of alternative formats such as Braille, large prints, talking books and the availability of reading aids, volunteers and transcription services in libraries serving persons with visual impairment in Nigeria will go a long way in making information accessible to the blind and partially sighted. It is believed that the availability of various alternative formats of information resources will greatly enhance their utilization. Ogba (2000) reported that visually impaired users of the Imo State Library Board visit the library section for the visually handicapped to use and borrow Braille books, moon type, talking books on cassette, large print periodicals and books. Ogba further stated that apart from moon type, there are numerous volumes of Braille and periodicals on various subjects which provide satisfaction for the visually impaired users.

Visually impaired pupils use information resources for various purposes. They could be used for educational development, literacy acquisition, recreation, personal development, spiritual inspiration and as hobbies. Basharu (2000) noted that the number of blind persons who come to the Anglo-Nigerians Welfare Association for the Blind (ANWAB) Library, Lagos, either read or borrow alternative formats for use in their spare time. Basharu also noted that an estimate of about $95 \%$ of the users always require reading materials, as they either borrow from the library or they bring printed matter to be transcribed to Braille for their reading pleasure.

Various alternative formats of information resources are used by the visually impaired based on their availability. In their study, Adetoro and Atinmo (2012) discovered that Braille materials enjoyed high frequency of use among the respondents. They noted that Braille was the most utilized format because it was the most available format in all the libraries they studied. Meanwhile, Singh and Moirangthem (2010) observed that the respondents in their study used audio books in the form of cassettes more than the digital DAISY talking books because almost all of them owned a tape record player, which is cheaper and easier to use than CD or DAISY. Similarly, the study conducted by Sehic and Tanackovic (2014) indicated that the preferred format by the respondents is not Braille but electronic resources. This is because assistive technologies play major role in their educational experiences. Thus, it becomes obvious that pupils use the most available format for meeting their information needs.

\section{Methodology}

The study adopted descriptive survey research design. The study was carried out in four special education centres established in South-East Nigeria. These special education Centres for the Blind are: Afara-Ukwu in Umuahia, Abia State; Basden Memorial Special Education Centre in Isulo, Anambra State; Special Education Centre in Opefia, Izzi L.G.A Ebonyi State; and Special Education Centre in Oji River, Enugu State. The population comprised 129 respondents, consisting of 125 visually impaired pupils and 4 librarians. There was no sample size because the population was manageable. Two instruments used for data collection were focus group discussion and interview. Focus group discussion was used for the students while interview was used for the librarians. Data collected were analyzed qualitatively.

\section{Presentation and analysis of Data Research Question}

What use do visually impaired primary school pupils make of library and information resources in South East Nigeria?

Results from the focus group discussions and interview with the librarians revealed that pupils used information resources for various purposes. Their responses showed that the resources were used for educational development, acquisition of literacy, religious and recreational purposes, personal development and as hobbies.

From the discussion, it was obvious that pupils visited the libraries but their use of information resources was limited by availability of readable format. They lacked textbooks in Braille, which is the major format for teaching and learning in all the schools. Lamenting their lack of Braille textbooks, one of the pupils from a group said: 
"We don't have textbooks in all the subjects except in English and Mathematics". He further said that "even the English and Mathematics textbooks are old modules". Similarly, in another group, pupils listed the subjects without textbooks by saying: "No Braille textbooks in Igbo, home economics, health education, Christian religious studies (CRS), English, civic education, agricultural science, social studies, computer science, basic science and technology".

Both the focus group discussions and interviews conducted revealed that Braille was a key factor in the utilization of information resources. During the interview with the librarian of the Anambra State Special Education Centre, he pointed out that in the past; Braille Foundation USA was sending them Braille books and magazines such as "Free matter for the blind" and Bibles. He particularly noted that these Braille works were really helpful in enabling pupils learn to read Braille. It is important to clarify here that these Braille materials did not contain classroom textbooks. According to him, Braille Bibles start with letters $\mathrm{A}, \mathrm{B}, \mathrm{C}, \ldots . \mathrm{He}$ went on to explain how the six dots of Braille are contracted to give meanings of words. These dots are arranged in Braille Bibles. As pupils read these Bibles, they learnt Braille and it helped them in reading other materials. Meanwhile, the librarian emphasized that it was very important for pupils to learn to read Braille early so that they could read and write external examinations. This is why they had library periods during which pupils went to the library to be taught Braille reading by the librarian.

However, lack of Braille resources was a major challenge that hindered the use of library resources by visually impaired pupils in the libraries under study. Many pupils expressed their unhappiness with non-availability of Braille resources. Except for English language and mathematics (in some cases) virtually all the subjects lacked Braille textbooks.

Even in religious studies, some centres had incomplete Braille books of the Bible. For instance, in one of the groups during the discussion, a pupil in his response said "Even the Bible is incomplete; I have been looking for Psalm 115 to read but could not find it". If the library resources were in Braille, the pupils would be motivated to read them. This was the opinion of the librarians. Pupils also noted that the centres had no current affairs resources in Braille, no Braille reference materials like dictionaries and no story books of interest in Braille. For instance, in Enugu State, the centre had few copies of old Braille Macmillan textbooks in English and mathematics sent by Niger wives long ago; there were none in other subjects. These were not useful to pupils. The centre however had many print textbooks in English language, Mathematics and other subjects. These print textbooks were stocked away in the headmistress' office since they could not be used by pupils. Another challenge peculiar to this centre was that it contained Braille textbooks that were above the level of pupils. These books donated by Enugu state indigenes abroad were suitable for secondary school students and university undergraduates; as such they were not used by pupils. Being of no use to pupils, the books were also packed in cartons in the library. (See figure 1). Also, some magazines sent to the centre by foreign bodies such as Touch Trust Foundation of USA were above the level of pupils, for instance, 'Legend in Sports' is one of such magazines.

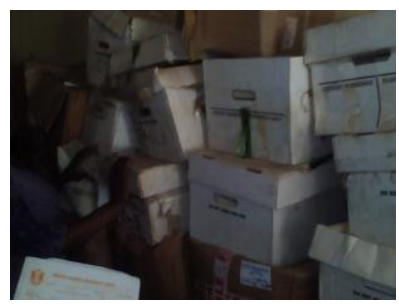

Fig. 1: Cartons of Books not used 
Ebonyi State equally had limited copies of Braille English and Mathematics textbooks, also sent by Nigerwives between 2001 and 2004. However, the centre library had many print textbooks in English, Mathematics and other subjects. It is the centre that had the highest collection of print resources. (See fig 2). Print resources were of no benefit to the visually impaired. Abia

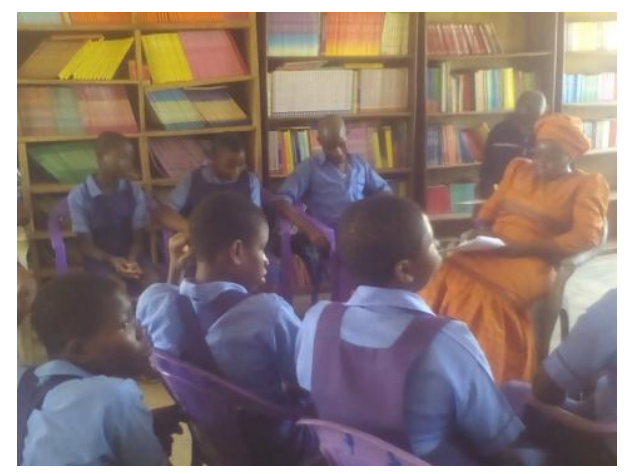

Fig. 2: Print Textbooks in Ebonyi State Library

The researchers were particularly interested to know how the teaching and learning process takes place in the centres that lack Braille resources or centres with print resources. That is, how do the teachers teach? how do pupils learn, take notes, write examination and how is their performance? The interview revealed that teachers teach by dictating what would be taught to pupils who copy them using Braille boards. Pupils were expected to have their own Braille boards because with that they take down notes which they read in preparation for examination. The teachers made out time to dictate to the pupils before the lessons. Sometimes, it might be two times a week. In other words, a teacher could decide to dictate today and teach tomorrow.

With regards to the Mathematics and English textbooks, the researchers wanted to know if they also dictate them. They were told that Mathematics and English textbooks were also
State had a better Braille collection in English language and mathematics donated by Niger wives as well. It had no print collection. It was only in Anambra State that Universal Basic Education Commission (UBEC) in 2012 supplied the centre current editions of Braille mathematics, social studies and basic science and technology textbooks. The librarian affirmed that pupils used the Braille resources. The centre had scanty collection of print resources.

dictated. When mathematics is dictated, pupils copy and solve with Tailor's frame and types. The researchers were told that Tailor's frame has openings, and it is set using types. After solving, the pupils write the answers in Braille.

In relation to writing examination, the researchers were told that pupils write in Braille. Teachers who could read Braille mark, but those who could not, would get pupils to read the answers for them. Pupils in primary schools do not use typewriters to write examinations. Even their primary six final examinations are written in Braille. Pupils start learning typewriting in primary four so that they would master it before getting into the mainstream of education in secondary schools. On the issue of performance, the researchers were told that some of the pupils perform very well, be it terminal examination, first school certificate or common entrance examinations. Hence, they are in different secondary schools and universities. For instance, the researchers were told that an old pupil of Special Education Centre Umuahia was one time President of Law Students Association of University of Lagos.

In the same vein, audio resources were conspicuously not available in all the centre libraries visited. As such pupils were not using facilities like audio/talking books, audio tapes, CDs and radios. Even the digital formats, 
pupils did not use them, though there were computers in some of the centres. The computers were mainly for administrative purposes. Necessary software and hardware were not installed; hence pupils could not use them. Responses from one of the groups confirmed this when the pupils echoed, "we have computer office but no computers" This was a clear indication that they were not using digital forms. Non-exposure to other formats than Braille limited them to the use of Braille, and Braille resources were not adequately provided.

\section{Discussion of Results}

Findings from the focus group discussion revealed that the pupils were not making use of available resources to a high extent. This was due to the fact that most of the resources, especially textbooks, were in print, a format they were not able to read. Therefore, resources were deemed not available in many centres. Braille resources available in all the centres in large quantity were religious materials, such as the books of the Bible and Christian magazines. Pupils use what they have in Braille. So they read the Bible, Christian magazines, story books culled from the Bible. A few of them use textbooks where they are available, for instance, in Anambra State where Braille textbooks were provided in three subjects, pupils used them.

Audio resources and ICT resources or assistive technologies were not used at all by the pupils. Skeletal audio services used by pupils were dictation of notes by teachers and reading of story books to their hearing by friends and relations. Non-utilization of these resources was attributed to non-availability. This collaborates with the findings of Adetoro and Atinmo (2012) who asserted that knowledge of reading interest of visually impaired persons was mandatory before transcription. Adetoro (2011) also noted that information materials can only become usable to persons with visual impairment when they are transcribed into alternative formats. The implication of this is that pupils were not making use of these resources because they were not transcribed into Braille so that they can read them. Singh and Moirangthem (2010) indicated that all the libraries they studied except one had audio book recording studios, provide computer training and internet services. They also noted that three out of the seven libraries they studied had their own Braille press which produce books or magazines in Braille. Also, Audio Information Network of Colorado (AINC) records and broadcasts audio recordings of materials that are usually not available in audio format for example newspapers, magazines, children's programme, etc, (Houghton \& Sitter, 2010). Meanwhile, in the finding of Sehic and Tanackovic (2014) the preferred format was not Braille but electronic resources. This could be attributed to the availability of electronic resources. Ekwelem (n.d.) asserted that the only electronic resources available to visually impaired library users were taped books and online public access catalogue (OPAC). There is need to provide various formats of information resources so that pupils will be exposed to their use. This will enable them to choose the ones they prefer in order to access information for educational developments.

\section{Recommendations}

Information resources should be provided in alternative formats readable to the visually impaired pupils. Efforts should be made to provide resources in Braille, audio or ICT formats in all the subjects taught in the schools. The state governments should increase their subventions to the centres so that there would be enough funds to produce some of the resources locally. Also, thestate governments should recruit Braille typists to replace retiring ones so that they could help to transcribe some of the needed resources into Braille. There is need for employment of more qualified teachers, school librarians and volunteerism either from churches, private organizations and concerned citizens among others in the special education centres in Nigeria. 


\section{References}

Adetoro, N. (2011). Availability and use of information materials by persons with visual Impairment in Nigeria. Information, Society and Justice, 4(2), 5 - $\quad 18 . \quad$ Retrieved from http://www.ajol.info/index.php/ajlais/art icle.

Adetoro, N. \& Atinmo, M. (2012). Reading interest and alternative format utilization by the visually impaired in Nigeria. Journal of Library, Archives and Information Science, 22 (1).Retrieved from

http://www.ajol.info/index.php/ajlais/art icle.

Ajobiewe, T. (1999). Developing library information policy for persons with visual impairment in developing countries. Retrieved from http://icevi.org/publications/ic

vi_wc200603\%20\%20\%20access\%20_t o_\%20literacy_th---

Basharu, D. (2000). Equipping Libraries for the Blind with Reading Materials.Journal of Association of Libraries for the Visually Impaired, 1(1), 56 - 61.

Copyright for Visually Impaired Persons (n. d.) Factsheet.

Eguavoen, O. E. I. \& Eniola, M. S. (2007). The relevance of library and information services for the visually impaired in Nigeria. Nigerian Library Link, 5(2), 88-96.

Ekwelem, V. O. (n.d). Library services to disabled students in the digital era: challenges for outcome assessment. Library Philosophy and Practice(ejournal)

http://digitalcommons.unl.edu/libphilpra $\mathrm{c}$

Houghton, V \& Sitter, C. (2010). Serving the blind and visually impaired in Colarado: A resource for librarians. MODULE BP http://www.unicef.org.uk
100. MA/MSc Information Studies, University of Northumbria- Newcastle

National Dissemination Centre for Children with Disabilities (NICHCY)(2012).Visual impairment, including blindness. Disability Facts Sheet 13.

Ogba, U. (2000). Library and Information Services to the Physically Handicapped in Library for the Handicapped, Imo State Library Board, Owerri. Journal of Association of Libraries for the Visually Impaired, 1 (1), 10-14

Onifade, F. N. \& Sowole, A. O. (2009). Use and Non-Use of Books in a Nigerian University of Agriculture Library. Journal of Library and Information Science (JOLIS),6(1),76 -

77

Rayini, J. (2017). Library and information services to the visually impaired persons. Library Philosophy and Practice (e-journal). 1510. Retrieved from http://digitalcommons.unl.edu /libphilprac/1510

Sehic, S. \& Tanackovic, S. F. (2014). Exploration of academic Information Seeking and Library use of the blind and visually impaired students in Croatia. Retrieved from http://ozk.hr/proceedings/index.phplida/ article/viewFile/158/156

Singh, K. P. \& Moirangthem, E. (2010). Are Indian libraries VIP- friendly? Information use and information seeking behavior of visually impaired people in Delhi libraries. Library Philosophy and Practice. Retrieved from http://digitalcommons.unl.edu

Ugwu, A. B. C. (2008). Elements of special education for higher education. Enugu: Fred-Ogah publishers. United Nations Convention on the Right of the Child (1990). fr 